\title{
Is Stock Price Synchronicity a Measure of Noise or Stock Price Informativeness: Evidence from Audit Pricing Model
}

\author{
Jim Wang (corresponding author) \\ School of Business, Tung Wah College \\ Mongkok, Kowloon, Hong Kong \\ Tel: (852) $34686871 \quad$ E-mail: jimwang@twc.edu.hk
}

\begin{abstract}
Received: August 3, 2014 Accepted: August 23, $2014 \quad$ Published: December 1, 2014
doi:10.5296/ajfa.v6i2.6062 URL: http://dx.doi.org/10.5296/ajfa.v6i2.6062
\end{abstract}

\begin{abstract}
It is an unsettled issue of whether stock price synchronicity (hereafter SYN) measures market-wide noise or market-wide informativeness. The Sarbanes-Oxley Act (hereafter SOX) provides an experimental setting to re-examine the issue of SYN. As internal control reports and assessments required by SOX are available to the stock market in annual reports, this market-wide financial statement-related information will affect auditors' risk assessment and therefore audit work and consequently audit fees as well. Using this experimental setting, this study uses an audit pricing model to examine the relation between audit fees and SYN.

Using a sample consisting of U.S. firms from 2004 to 2006, the study documents a significantly positive relation between audit fees and SYN only in year 2004, but insignificant relations in years 2005 and 2006. The results are consistent with SYN representing market-wide financial statement-related information in 2004 when a regulatory change in financial statements due to SOX; while SYN representing market-wide noise (i.e. non-financial statement-related information) in 2005 and 2006.
\end{abstract}

Keywords: Audit fee, Stock price synchronicity, Audit pricing model, $\mathrm{R}^{2}$, Stock price Informativeness

JEL Classification: M42, G34 


\section{Introduction}

Financial analysts and government regulatory agencies attach great importance to stock markets, which function as a resource-allocation mechanism by incorporating market-wide, industrial-wide and firm-level information into stock prices. The recent melt-down of global financial markets shows that stock markets are highly susceptible to market-wide news. Stock prices go up (down) when good (bad) news hits the market. As a consequence, individual stocks move synchronously or un-synchronously with the stock market as a whole. Stock price synchronicity (SYN) has been a very important topic for a number of prior studies (e.g. Roll, 1988; Morck et al., 2000). SYN is measured by the $\mathrm{R}^{2}$ of the "market model" 1 or $\log$-transformed $\mathrm{R}^{2}$, (i.e. $\log \left(\mathrm{R}^{2} /\left(1-\mathrm{R}^{2}\right)\right.$ ). Roll (1988) calculated the $\mathrm{R}^{2}$ (i.e. the coefficient of determinants) of the "market model" and found that the $\mathrm{R}^{2}$ is around 0.35 for monthly data and 0.20 for daily data using the CRSP U.S. data from 1982 to 1987 . The $\mathrm{R}^{2}$ should be close to 1.0 " (Roll, 1988; p542), which contradicts the belief that authenticated information, with hindsight, could explain most asset price movements. Roll (1988) argued that $\mathrm{R}^{2}$ "seems to imply the existence of either private information or occasional frenzy unrelated to concrete information". It is unclear whether SYN is caused by the noise of stock prices due to market sentiments or more market-wide information incorporated into stock prices.

Prior studies show mixed results. For example, Jin and Myers (2006), Piotroski and Roulstone (2004) and Chan and Hameed (2006) support that SYN measures informativeness. On the contrary, Yang and Zhang (2006), Skaife et al. (2006) and Li et al. (2014) suggest that SYN measures noise. It thus remains an unsettled issue whether SYN measures noise or informativeness.

This study re-examine the SYN issue. It differs from prior research on two grounds. First, this research uses an audit pricing model. Auditors are required to respond to information affecting material misstatements of financial statements by revising risk assessment and audit procedures. Thus, the audit pricing model can be used to test whether SYN measures financial statement-related information or noise (i.e. non-financial statement-related). Second, this research uses a post-SOX sample. SOX provides an experimental setting of regulatory changes regarding disclosure of internal control reports and assessment in annual reports. As internal control information is available for the first time in the post-SOX period, SYN is more likely to capture market-wide information. This sample helps to find the significant relation between audit fees and SYN.

The next section reviews the literature and describes the background of SOX. Section three develops testable hypotheses. Section four presents methodology used in empirical tests. Section five describes the sample and provides empirical results. The final section concludes.

\section{Literature Review and Sarbanes- Oxley Act Background}

\subsection{Literature Review}

Prior studies show mixed results on whether SYN measures informativeness or noise.

\footnotetext{
${ }^{1}$ Roll (1988) uses two versions of market model. One is the single factor model based on CAPM. The other is the multiple factors model based on APT.
} 
Morck et al. (2000) argued that SYN measures returns reflecting more market-wide information. Moreover, Jin and Myers (2006), Piotroski and Roulstone (2004) and Chan and Hameed (2006) argued that SYN measures informativeness. Jin and Myers (2006) documented a positive association between SYN and opaqueness, which is in line with the theory that opaqueness increases the ratio of market to total risk for investors and results in a high level of SYN. Piotroski and Roulstone (2004) found a positive association between SYN and analyst forecast revisions. Similarly, Chan and Hameed (2006) reported a positive association between SYN and analyst following, which is consistent with the theory that analyst following incorporates market-wide/industry-wide information into stock prices. In addition, Xing and Anderson (2011) argued that SYN represents public information by documenting an inversely U-shaped relation between SYN and proxies of firm-specific public information.

In contrast, Yang and Zhang (2006), Skaife et al. (2006) and Li et al. (2014) argued that SYN measures noise. Yang and Zhang (2006) tested the relation between SYN and post-earnings-announcement drift, V/P anomalies and earnings response coefficient, and their results support the noise interpretation of SYN. Skaife et al. (2006) examined the association between SYN and informativeness proxies from the following four aspects: 1) stock pricing of future earnings information, 2) analyst forecast errors, 3) cross-listing in the U.S. and 4) firm fundamentals. However, they found little evidence of SYN measuring informativeness. Li et al. (2014) found that SYN resembles noise. With all the conflicting findings mentioned above, whether SYN measures informativeness or noise thus remains an unsettled issue.

To add new insights on the issue, this study draws on audit pricing literature, which use audit pricing model as a research method to investigate various issues (e.g. Frankel et al. 2002; Asbaugh et al. 2003; Francis et al. 2005; Wang and Yang 2011). Based on this line of literature, if SYN measures market-wide informativeness (i.e. market-wide financial statement-related information), this will affect an auditor's assessment of risk of misstatement and consequently auditors will exercise more audit effort and thus charge high level of audit fees; if SYN measures market-wide noise or sentiment, this will not affect an auditor's assessment of risk of misstatement and consequently auditors will not exercise more audit effort and hence charge higher audit fees.

\section{2 Sarbanes-Oxley Act Background}

The Sarbanes-Oxley Act provides an experimental setting in this study. This study takes advantage of the SOX experimental setting by using a post-SOX sample of U.S. firms from 2004 to 2009. The Sarbanes-Oxley Act was approved by the Congress on July 25, 2002. SEC voted to adopt management's report on internal control (SOX section 404) on May 27, 2003. Accordingly, accelerated filers have been expected to comply for fiscal years since June 15 , 2004.

Section 404 of SOX requires each annual report to contain an internal control report. This internal control report should state the responsibility of management for establishing and maintaining adequate internal control procedures for financial reporting. The report should also contain an assessment of the effectiveness of the internal control. In addition, section 404 
specifically requires that the attestation on internal control shall not be the subject of a separate engagement. Thus, a public accounting firm which issues audit reports shall attest to internal control assessment made by the management. The attestation shall be made in accordance with standards for attestation engagements issued or adopted by the PCAOB (the Public Company Accounting Oversight Board).

Based on SEC release No. 33-8183, fees for attestation services on internal control assessment belong to the audit fees category. Overall, these regulatory rules significantly change the structure of audit fees between pre-SOX and post-SOX periods.

\section{Hypothesis Development}

\subsection{Link between Audit Fees and SYN}

Auditors are hired as an external monitoring mechanism to mitigate agency problems according to the agency theory (Watts \& Zimmerman, 1980). Based on GAAS (Generally Accepted Auditing Standards), audit procedures ensure that auditors understand their clients in terms of client business environment and governance, and identify areas venerable to misstatements and errors or frauds and consequently auditors' tests can be adequate and effective. For example, the first standard of field work requires auditors to "adequately plan the work" (Auditing Standards SAS No. 105, Amendment to Statement on Auditing Standards No.95); the second standard of field work requires auditors to "obtain a sufficient understanding of the entity and its environment, including its internal control, to assess the risk of material misstatement whether due to error or fraud, and to design the nature, timing and extent of further audit procedures" (Auditing Standards SAS No. 105, Amendment to Statement on Auditing Standards No.95).

Moreover, auditors need to assess audit risk, which is "the likelihood of material errors in the client's financial statements" (Gul \& Tsui, 1998, p221; Accounting Standards Board, Statement on Auditing Standards, No. 47). Overall, auditors face three kinds of audit risk: 1) "inherent risk", which is the likelihood of environmental factors producing a material error without taking account of internal control quality; 2) "control risk", which is the likelihood that the internal control system fails in preventing or detecting of a material error; and 3) "detection risk", which is the likelihood of failures of audit procedures in detecting a material error unfound by the internal control system. With respect to clients of greater inherent risk/control risk, auditors will use more resources to obtain "sufficient appropriate audit evidence" to lower "detection risk". Auditors" assessment of clients' risk of misstatement can be used to test the two competing SYN arguments: 1) SYN informativeness argument and 2) SYN noise argument. Morck et al. (2000), Jin and Myers (2006), Piotroski and Roulstone (2004) and Chan and Hameed (2006) support the SYN informativeness argument. They argued that SYN measures returns reflecting more market-wide information. On the contrary, Yang and Zhang (2006), Skaife et al. (2006) and Li et al. (2014) support the SYN noise argument because of insignificant associations between SYN and informativeness measures.

One the one hand, if SYN measures market-wide informativeness (i.e. market-wide financial statement-related information such as SOX internal control requirements), this will affect an 
auditor's assessment of risk of misstatement and consequently will affect audit procedures, audit effort and audit fees, thus predicting a significantly positive relation between audit fees and SYN.

On the other hand, if SYN measures market-wide noise or sentiment, this will not affect an auditor's assessment of risk of misstatement and consequently will not affect audit effort or audit fees, thus predicting no significant association between audit fees and SYN.

\subsection{Hypothesis Development}

2004 was the first fiscal year when internal control information was required by SOX section 404 available to the market, thus resulting in market-wide financial statement-related information. In 2004, SYN measured market-wide financial statement-related information. Auditors had to respond to SYN caused by first-time internal control information available to the market and assess the effect on the risk of material misstatement of financial statements. Consequently, auditors spent more resources and thus charged higher audit fees. According to A.R.C. Morgan (2005), the estimated initial section 404 compliance was estimated at $\$ 1$ million per $\$ 1$ billion in revenue. The disclosed average cost of external resources for section 404 compliance ranged from $\$ 1.56$ million for firms with annual sales less than \$250 million to $\$ 10$ million for firms with annual sales between $\$ 7$ billion and $\$ 10$ billion (A.R.C. Morgan, 2005). This leads to the first hypothesis.

Hypothesis 1: there was a significantly positive relation between audit fees and SYN in 2004.

In comparison to 2004, this internal control information is no longer new to auditors in 2005 and 2006. In 2005 and 2006, SYN was more likely to measure noise or sentiment because the market had incorporated internal control information in 2004 and internal control information is no longer new to the market. Therefore, auditors are less likely to respond to internal control information as they did for the first time in 2004 unless there are significant changes in the internal control of their clients. It is assumed that there were no significant changes in the internal control in 2005 and 2006 compared with 2004, and thus there were no changes in auditors' responses to risk assessment, audit effort and, as a result, audit fees, which leads to the second hypothesis.

Hypothesis 2: there was no significant relation between audit fees and SYN in 2005 and 2006.

\section{Methodology}

\subsection{Stock Price Synchronicity}

SYN measures how firms' stock returns are closely tied to market and industry returns. Following prior research works (e.g. Morck et al., 2000; Durnev et al., 2003; Durnev et al., 2004), the SYN measure is derived from the $\mathrm{R}^{2}$ of the following regression:

$\mathrm{RET}=\mathrm{a}+\mathrm{b}_{1} \mathrm{MARET}_{\mathrm{t}}+\mathrm{b}_{3} \operatorname{INDRET}_{\mathrm{t}}+\varepsilon$

The weekly return (RET) of each firm is defined as the compounded return over five consecutive trading days within each week. Each firm's weekly industry return (INDRET) is 
calculated as the value-weighted average of firms' weekly returns, using all firms within the same two-digit SIC code excluding the firm in question. For each firm year's observations, weekly returns are regressed on the value-weighted market returns and value-weighted two-digit SIC industry returns. According to Piotroski and Roulstone (2004), a minimum of 45 weekly observations is required for each firm year to retain sufficient observations for regression by each firm year.

Stock price synchronicity (SYN) is defined as follows:

$\mathrm{SYN}=\log \left(\mathrm{R}^{2} /\left(1-\mathrm{R}^{2}\right)\right)$

where $\mathrm{R}^{2}$ is the coefficient of determination from the estimation of the above equation (1).

\subsection{Auditing Pricing Model}

Simunic (1980) regarded audit service as economic goods to the auditee (i.e. the client) and built a positive analytical model in which an auditor, as a supplier of a service, performs the work under the demands of a customer. For the customer (i.e. auditee), the consumption of auditing and the consumption of internal accounting control system are mutual substitutes and complements. Moreover, the demand for auditing or internal accounting control systems is affected by the potential legal liability of auditees and auditors to third-party users of financial statements (i.e. litigation risk). Regarding auditors and auditees, Simunic (1980) assumed that 1) both auditors and auditees are risk-neutral and maximize their expected profits; and 2) auditors and auditees jointly share their proportion of users' financial losses caused by omissions or misrepresentations in audited financial statements ${ }^{2}$. Under these assumptions, the marginal benefit (or loss avoidance) of an internal accounting system (auditing) is decreasing at an increasing rate with more input of auditing (internal accounting control). Thus, the equilibrium demand for auditing service is determined by the marginal benefit and the cost of the auditing/internal accounting control system.

The equilibrium demand for auditing shows that audit pricing is determined by the loss exposure of the auditee, the loss-sharing ratio between auditors and auditees, and auditors' production functions (Simunic, 1980). Regarding the loss exposure of the auditee, it increases litigation risk (i.e. the possibility of undetected omissions or material misstatements in financial statements discovered after auditors issued their opinion reports).

Talking to professionals from both audit firms and insurance organizations providing liability coverage for auditors, Simunic (1980) indentified and measured five determinant factors in loss exposure. The first factor is the client (or auditee) size in terms of total assets rather then revenues. Because auditing processes are based on sampling, increases in total assets together with individual components of total assets can increase the sample size required to achieve a given confidence level. The second factor is the client's business operation complexity and diversification, with complexity measured by the number of subsidiaries and diversification

\footnotetext{
${ }^{2}$ Section 11(f) of the Securities Act 1933 and section 18 (b) of the Securities Exchange Act of 1934 provide for joint and several liability on the part of auditees and auditors. Under these provisions, the entire amount of damages suffered by a third party can be controlled from any one of the liable persons, with that person generally retaining rights to collect from all other persons who are also liable.
} 
measured by the number of business segments (i.e. two-digit SIC industries of the client's operation) and the percentage of foreign assets to total assets. More complex and diversified business operation increases the number of business decision centers and therefore the loss exposure. The third factor is certain high-risk line items of financial statements (e.g. inventory and accounts receivables) measured by the ratio of receivables to total assets or the ratio of inventory to total assets ${ }^{3}$. Both receivables and inventory are "risky" items on balance sheets because these items need specific confirmation and observation auditing procedures and the valuation of these items is based on assumptions of forecasts on future events. The fourth factor is the industry of the client's operation because loss exposure is likely to vary from industry to industry. The fifth factor is the client status as a publicly listed or privately held company ${ }^{4}$.

The loss-sharing ratio is determined by the financial insolvency (financial distress) of both the auditor and the auditee. However, there is almost no data available to assess the financial difficulty of auditors, and thus the focus is on the following measures of the client's insolvency: 1) the client's profitability, measured by the ratio of net income to total assets (i.e. the accounting rate of return); 2) a loss indicator on whether the client endures loss over the period of the current year or two previous years; and 3) an indicator of a qualified audit opinion $^{5}$ (including going-concern opinion) in the current year.

Auditors' production functions (i.e. the scale of economies) are not directly observable. However, differentiated audits are manifested through price differences associated with product characteristics (e.g. the brand-name of auditors). Big auditors provide a higher level of assurance than non-big auditors (Palmrose, 1988).

\subsection{Empirical Model}

Based on the research works by Simunic (1980), Palmrose (1986), Frankel et al. (2002), Asbaugh et al. (2003) and Francis et al. (2005), the following audit pricing model is used to test the audit pricing of SYN:

$$
\begin{aligned}
& L A F=b_{0}+b_{1} L T A+b_{2} L S E G+b_{3} C A T A+b_{4} Q U I C K+b_{5} D E+b_{6} R O A+b_{7} F O R E I G N+ \\
& b_{8} \text { OPINION }+b_{9} Y E+b_{10} L O S S+b_{11} B I G+b_{12} S Y N+\text { industry effect }
\end{aligned}
$$

Where:
LAF
$=$ natural log of audit fees in dollars
LTA $\quad=$ natural $\log$ of total assets in millions of dollars
LSEG $\quad=$ natural log of number of unique business segments
CATA $\quad=$ ratio of current assets to total assets
QUICK $\quad=$ ratio of current assets (less inventory) to current liabilities
$\mathrm{DE} \quad=$ ratio of long-term debt to total assets
ROA $=$ ratio of earnings before extraordinary items to total assets

\footnotetext{
3 Total assets in the denominator is used to control cross-sectional variation in firm size.

${ }^{4}$ Most previous studies and this research use the sample of publicly listed companies and thus there is no variation in the client status.

${ }^{5}$ Qualified audit opinions indicate either a significant deviation from the GAAP (generally accepted accounting principle) or a scope of limitation on certain areas of financial statements, which show significant uncertainties of clients.
} 


$\begin{array}{ll}\text { FOREIGN } & =\text { proportion of total sales from foreign operations } \\ \text { OPINION } & =\text { indicator variable, } 1=\text { qualified audit report } \\ \text { YE } & =\text { indicator variable, } 1=\text { non-Dec } 31 \text { year end } \\ \text { LOSS } & =\text { indicator variable, } 1=\text { loss in current fiscal year } \\ \text { BIG } & =\text { big auditors } \\ \text { SYN } & =\text { stock price synchronicity } \\ \text { industry effects } & =\text { industry dummy variables for two-digit SIC industry }\end{array}$

Audit fees are the dependent variable. The independent variables client size LTA (measured by total assets), the client's business operation complexity LSEG (measured by the number of business segments), the client's operation diversity FOREIGN (measured by the proportion of total sales from foreign operations) and industry effects are measures of the loss exposure of the auditee. Return on assets ROA, a loss dummy LOSS and an indicator of a qualified audit opinion OPINION are measures of the client's insolvency. A big auditor dummy BIG measures the premium of auditors' brand-name (i.e. auditors' production functions). In addition, a dummy of a non-calendar year end YE is included to control the non-busy season in auditing; the current ratio CATA (measured by the ratio of current assets to current liabilities), the quick ratio QUICK (measured by the ratio of current assets excluding inventory to current liabilities) and the financial leverage DE (measured by the long-term debt to total assets) are also included to control the client's risk.

The variable of interest is SYN. Based on hypothesis $1, b_{12}$ is expected to be significantly positive in 2004. Based on hypothesis 2, $b_{12}$ is expected to be insignificant in 2005 and 2006.

\section{Sample and Results}

\subsection{Sample}

This study uses the post-SOX (Sarbanes-Oxley Act) sample period from 2004 to 2006 for two reasons. First, most previous studies were conducted with the pre-SOX sample. There is a scarcity of research using the post-SOX sample. Second, the structures of audit fees are significantly different between pre-SOX and post-SOX. Thus, the post-SOX sample is homogenous in terms of the structures of audit fees.

The audit fee data are from Audit Analytics. The financial variable data are from Compustat. The data of stock market returns used to calculate stock price synchronicity are from CRSP. The daily return and market return data are from CRSP and the data of weekly return are calculated by using the daily return data. All databases used in this study are from Wharton Research Data Service. By following Piotroski and Roulstone (2004), a minimum of 45 weekly observations is required to calculate SYN for each firm-year. Regarding the unavailable data on analyst forecast revisions, changes in institutional ownership and insider trading are assumed to be "zero". ${ }^{6}$ After excluding observations with missing values, the

\footnotetext{
${ }^{6}$ The reported results of this study use the sample with these "zero" observations. However, this study also conducts tests without these "zero" observations. The unreported results show that the pooled regression results remain unchanged without these "zero" observations, while the results of annual regressions show insignificant coefficients on both abnormal audit/non-audit fees.
} 
sample size is 9,056 firm-year observations over the period of 2004 to 2006 . The final sample size is 7,884 firm-year observations after excluding top and bottom $1 \%$ outliers $^{7}$, with 2,903 , 2,732, 2,249 firm-year observations for 2004, 2005 and 2006 respectively.

\subsection{Results}

Table 1. Descriptive Statistics $(\mathrm{N}=7,884)$

\begin{tabular}{lcccccc}
\hline \multicolumn{1}{c}{ Variable } & Minimum & Q1 & Mean & Median & Q3 & Maximum \\
\hline AUDIT_FEES & 0 & 119000 & 1391425 & 445000 & 1257000 & 90200000 \\
NON_AUDIT_FEES & 0 & 11428 & 419153.3 & 68190 & 282000 & 55100000 \\
LAF & 0 & 11.687 & 12.815 & 13.006 & 14.044 & 18.318 \\
LNONF & 0 & 9.344 & 9.869 & 11.130 & 12.550 & 17.825 \\
LTA & 0.001 & 3.302 & 5.123 & 5.146 & 6.901 & 12.509 \\
LSEG & 0.693 & 0.693 & 1.047 & 0.693 & 1.386 & 3.219 \\
CATA & 0 & 0.300 & 0.521 & 0.520 & 0.744 & 1 \\
QUICK & 0 & 0.822 & 3.658 & 1.395 & 2.705 & 2348 \\
DE & 0 & 0 & 0.246 & 0.078 & 0.265 & 219 \\
ROA & -2038 & -0.140 & -1.777 & 0.022 & 0.071 & 40.96 \\
FOREIGN & -0.4 & 0 & 0.186 & 0 & 0.320 & 2.117 \\
OPINION & 0 & 0 & 0.432 & 0 & 1 & 1 \\
YE & 0 & 0 & 0.300 & 0 & 1 & 1 \\
LOSS & 0 & 0 & 0.410 & 0 & 1 & 1 \\
BIG & 0 & 0 & 0.681 & 1 & 1 & 1 \\
SYN & -10.635 & -2.628 & -1.805 & -1.593 & -0.755 & 1.804 \\
\hline
\end{tabular}

The variables are defined as follows:

$\begin{aligned} \text { AUDIT_FEES } & =\text { audit fees in dollars } \\ \text { NON_AUDIT_FEES } & =\text { non-audit fees in dollars } \\ \text { LAF(LNONF) } & =\text { natural log of audit (non-audit) fees in dollars } \\ \text { LTA } & =\text { natural log of total assets in millions of dollars } \\ \text { LSEG } & =\text { natural log of number of unique business segments } \\ \text { CATA } & =\text { ratio of current assets to total assets } \\ \text { QUICK } & =\text { ratio of current assets (less inventories) to current liabilities } \\ \text { DE } & =\text { ratio of long-term debt to total assets } \\ \text { ROA } & =\text { ratio of earnings before extraordinary items to total assets } \\ \text { FOREIGN } & =\quad \text { proportion of total sales from foreign operations } \\ \text { OPINION } & =\quad \text { indicator variable, } 1=\text { qualified audit report } \\ \text { YE } & =\quad \text { indicator variable, } 1=\text { non-Dec } 31 \text { year end } \\ \text { LOSS } & =\quad \text { indicator variable, } 1=\text { loss in current fiscal year } \\ \text { BIG } & =\quad \text { big auditors } \\ \text { SYN } & =\quad \text { stock price synchronicity }\end{aligned}$

\footnotetext{
7 The final sample excludes observations of top and bottom $1 \%$ in audit fees (LAF), total assets (LTA), current ratios (CATA), quick ratios (QUICK), leverage (DE), return on assets (ROA), proportion of foreign operation (FOREIGN) and stock price synchronicity (SYN).
} 
Table 1 shows the descriptive statistics of the audit pricing model. There are 7,884 firm-year observations with 2,903, 2,732, 2,249 firm-year observations for 2004, 2005 and 2006 respectively. Table 1 also shows that non-audit fees are much lower than audit fees in the post-SOX period, which is caused by the restrictions of SOX (Sarbanes-Oxley Act) on non-audit services.

Table 2. Regression Results of Audit Pricing Model

The regression results of the following audit/non-audit fee model:

$L A F=b_{0}+b_{1} L T A+b_{2} L S E G+b_{3}$ CATA $+b_{4} Q U I C K+b_{5} D E+b_{6} R O A+b_{7}$ FOREIGN + $b_{8} O P I N I O N+b_{9} Y E+b_{10} L O S S+b_{11} B I G+$ industry effect + year effect

\begin{tabular}{lcc}
\hline & \multicolumn{2}{c}{ Audit fee model } \\
\hline Variable & Estimate & p value \\
\hline Intercept & & \\
LTA & 9.011 & $<.0001$ \\
LSEG & 0.594 & $<.0001$ \\
CATA & 0.223 & $<.0001$ \\
QUICK & 0.478 & $<.0001$ \\
DE & -0.001 & 0.004 \\
ROA & 0.004 & 0.294 \\
FOREIGN & 0.000 & 0.952 \\
OPINION & 0.282 & $<.0001$ \\
YE & 0.218 & $<.0001$ \\
LOSS & -0.138 & $<.0001$ \\
BIG & 0.180 & $<.0001$ \\
IND1 & 0.135 & $<.0001$ \\
IND2 & 0.355 & $<.0001$ \\
IND3 & 0.216 & $<.0001$ \\
IND4 & 0.171 & $<.0001$ \\
IND5 & 0.332 & $<.0001$ \\
IND6 & 0.265 & $<.0001$ \\
IND7 & -0.440 & $<.0001$ \\
IND8 & -0.088 & 0.089 \\
IND9 & -0.233 & 0.00013 \\
IND10 & -0.033 & \\
IND11 & & \\
y2004 & 0.378 & \\
y2005 & 0.179 & \\
\hline $\mathrm{N}$ & -0.213 & \\
\hline 2 & -0.039 & \\
\hline & & \\
\hline
\end{tabular}


The variables are defined as follows:

$$
\begin{aligned}
\text { LAF(LNONF) } & =\text { natural log of audit (non-audit) fees in dollars } \\
\text { LTA } & =\text { natural log of total assets in millions of dollars } \\
\text { LSEG } & =\text { natural log of number of unique business segments } \\
\text { CATA } & =\text { ratio of current assets to total assets } \\
\text { QUICK } & =\text { ratio of current assets (less inventories) to current liabilities } \\
\text { DE } & =\text { ratio of long-term debt to total assets } \\
\text { ROA } & =\text { ratio of earnings before extraordinary items to total assets } \\
\text { FOREIGN } & =\text { proportion of total sales from foreign operations } \\
\text { OPINION } & =\text { indicator variable, } 1=\text { qualified audit report } \\
\text { YE } & =\text { indicator variable, } 1=\text { non-Dec } 31 \text { year end } \\
\text { LOSS } & =\text { indicator variable, } 1=\text { loss in current fiscal year } \\
\text { BIG } & =\text { big auditors }
\end{aligned}
$$

\begin{tabular}{|c|c|c|c|}
\hline Variable & Estimate & $\mathrm{t}$ value & $\mathrm{p}$ value \\
\hline Intercept & 9.579 & 162.44 & $<.0001$ \\
\hline LTA & 0.542 & 80.82 & $<.0001$ \\
\hline LSEG & 0.218 & 13.29 & $<.0001$ \\
\hline CATA & 0.494 & 11.07 & $<.0001$ \\
\hline QUICK & -0.043 & -9.75 & $<.0001$ \\
\hline $\mathrm{DE}$ & 0.031 & 0.59 & 0.557 \\
\hline ROA & -0.47 & -8.43 & $<.0001$ \\
\hline FOREIGN & 0.345 & 10.99 & $<.0001$ \\
\hline OPINION & 0.155 & 8.64 & $<.0001$ \\
\hline YE & -0.222 & -13.49 & $<.0001$ \\
\hline LOSS & 0.093 & 4.06 & $<.0001$ \\
\hline
\end{tabular}

The 11 industry dummies (IND1-IND11) are the two-digit SIC industries of 37, 87, 50, 13, 48, 49, 35, 38, 36, 28 and 73 respectively.

For brevity of reporting ${ }^{8}$, Table 2 presents the results of the pooled regression of the audit pricing model without SYN. However, audit fee regressions are run each year by industry with a requirement of at least 10 observations for each industry in each year. Table 2 shows that the $\mathrm{R}^{2}$ of the audit fee model is 0.59 , which is comparable to the $\mathrm{R}^{2}$ of 0.66 of DeFond et al. (2002, Table 4) and 0.66 of Ashbaugh et al. (2003, Table 2).

Table 3. Regression Results of Audit Pricing of SYN

The results of the pooled regression on the audit pricing of stock prince synchronicity:

\footnotetext{
${ }^{8}$ The unreported results show that most mean coefficients of regressions by each industry and year are insignificant compared the reported pooled regression results.
} 


\begin{tabular}{lccc}
\hline BIG & 0.266 & 11.86 & $<.0001$ \\
SYN & 0.018 & 2.42 & 0.015 \\
IND1 & -0.273 & -5.64 & $<.0001$ \\
IND2 & 0.006 & 0.13 & 0.896 \\
IND3 & -0.337 & -7.98 & $<.0001$ \\
IND4 & 0.176 & 5.39 & $<.0001$ \\
IND5 & 0.287 & 9.32 & $<.0001$ \\
IND6 & 0.117 & 4.1 & $<.0001$ \\
IND7 & 0.058 & 1.98 & 0.048 \\
IND8 & 0.362 & 14.46 & $<.0001$ \\
y2004 & -0.239 & -11.64 & $<.0001$ \\
y2005 & -0.005 & -0.22 & 0.829 \\
\hline $\mathrm{N}$ & & 7884 & \\
\hline $\mathrm{R}^{2}$ & & 0.727 &
\end{tabular}

The above sample excludes the top and bottom 1 percentiles of LAF, LTA, CATA, QUICK, DE, ROA, FOREIGN and SYN. The variables are defined as follows:

\begin{aligned} \hline LAF & $=$ natural log of audit fees in dollars \\ LTA & $=$ natural log of total assets in millions of dollars \\ LSEG & $=$ natural log of number of unique business segments \\ CATA & $=$ ratio of current assets to total assets \\ QUICK & $=$ ratio of current assets (less inventories) to current liabilities \\ DE & $=$ ratio of long-term debt to total assets \\ ROA & $=$ ratio of earnings before extraordinary items to total assets \\ FOREIGN & $=$ proportion of total sales from foreign operations \\ OPINION & $=$ indicator variable, $1=$ qualified audit report \\ YE & $=$ indicator variable, $1=$ non-Dec 31 year end \\ LOSS & $=$ indicator variable, $1=$ loss in current fiscal year \\ BIG & $=$ big auditors \\ SYN & $=$ stock price synchronicity \\ industry effects & $=$ industry dummy variables for two-digit SIC industry \end{aligned}

The eight industry groups are two-digit SIC code of 13, 48, 49, 35, 38, 36, 28, 73 with more than 500 observations for each industry.

Table 3 presents the results for the pooled regression. Note that the $\mathrm{R}^{2}$ of the pooled regression is 0.727 , which is comparable to the $\mathrm{R}^{2}$ of 0.66 of DeFond et al. (2002, Table 4) and 0.66 of Ashbaugh et al. (2003, Table2). The coefficient on SYN is 0.018 and significant ( $p$ value of 0.015 ), which seems to support Hypothesis 1 not only in 2004 but also 2005 to 2006. However, the annual results of Table 4 support Hypothesis 1 in 2004 only. 


\section{Macrothink}

Table 4. Annual Regression Results of Audit Pricing of SYN

The results of the annual regressions on the audit pricing of stock prince synchronicity:

$L A F=b_{0}+b_{1} L T A+b_{2} L S E G+b_{3} C A T A+b_{4} Q U I C K+b_{5} D E+b_{6} R O A+b_{7}$ FOREIGN + $b_{8} O P I N I O N+b_{9} Y E+b_{10} L O S S+b_{11} B I G+b_{12} S Y N+$ industry effect

\begin{tabular}{|c|c|c|c|c|c|c|}
\hline \multirow[b]{2}{*}{ Variable } & \multicolumn{2}{|c|}{ year 2004} & \multicolumn{2}{|c|}{ year 2005} & \multicolumn{2}{|c|}{ year 2006} \\
\hline & Estimate & $\mathrm{p}$ value & Estimate & $\mathrm{p}$ value & Estimate & $\mathrm{p}$ value \\
\hline Intercept & 9.512 & $<.0001$ & 9.383 & $<.0001$ & 9.579 & $<.0001$ \\
\hline LTA & 0.533 & $<.0001$ & 0.557 & $<.0001$ & 0.526 & $<.0001$ \\
\hline LSEG & 0.208 & $<.0001$ & 0.21 & $<.0001$ & 0.245 & $<.0001$ \\
\hline CATA & 0.514 & $<.0001$ & 0.536 & $<.0001$ & 0.436 & $<.0001$ \\
\hline QUICK & -0.055 & $<.0001$ & -0.034 & $<.0001$ & -0.042 & $<.0001$ \\
\hline $\mathrm{DE}$ & 0.109 & 0.213 & 0.002 & 0.985 & 0.011 & 0.899 \\
\hline ROA & -0.491 & $<.0001$ & -0.623 & $<.0001$ & -0.28 & 0.002 \\
\hline FOREIGN & 0.267 & $<.0001$ & 0.381 & $<.0001$ & 0.397 & $<.0001$ \\
\hline OPINION & 0.154 & $<.0001$ & 0.133 & 0.000 & 0.241 & $<.0001$ \\
\hline YE & -0.532 & $<.0001$ & -0.028 & 0.326 & -0.031 & 0.273 \\
\hline LOSS & 0.083 & 0.029 & 0.091 & 0.024 & 0.099 & 0.012 \\
\hline BIG & 0.285 & $<.0001$ & 0.276 & $<.0001$ & 0.231 & $<.0001$ \\
\hline SYN & 0.028 & 0.02 & 0.012 & 0.374 & 0.012 & 0.301 \\
\hline IND1 & -0.301 & 0.000 & -0.216 & 0.015 & -0.285 & 0.000 \\
\hline IND2 & 0.004 & 0.962 & 0.029 & 0.722 & -0.017 & 0.83 \\
\hline IND3 & -0.341 & $<.0001$ & -0.353 & $<.0001$ & -0.297 & $<.0001$ \\
\hline IND4 & 0.262 & $<.0001$ & 0.15 & 0.01 & 0.087 & 0.118 \\
\hline IND5 & 0.338 & $<.0001$ & 0.237 & $<.0001$ & 0.284 & $<.0001$ \\
\hline IND6 & 0.162 & 0.001 & 0.068 & 0.173 & 0.11 & 0.022 \\
\hline IND7 & 0.153 & 0.002 & -0.004 & 0.943 & 0.033 & 0.486 \\
\hline IND8 & 0.402 & $<.0001$ & 0.359 & $<.0001$ & 0.299 & $<.0001$ \\
\hline $\mathrm{N}$ & \multicolumn{2}{|c|}{2903} & \multicolumn{2}{|c|}{2732} & \multicolumn{2}{|c|}{2249} \\
\hline $\mathrm{R}^{2}$ & \multicolumn{2}{|c|}{0.737} & \multicolumn{2}{|c|}{0.708} & \multicolumn{2}{|c|}{0.756} \\
\hline
\end{tabular}

The above sample excludes the top and bottom 1 percentiles of LAF, LTA, CATA, QUICK, DE, ROA, FOREIGN and SYN. The variables are defined as follows:

$$
\begin{aligned}
\text { LAF } & =\text { natural log of audit fees in dollars } \\
\text { LTA } & =\text { natural log of total assets in millions of dollars } \\
\text { LSEG } & =\text { natural log of number of unique business segments } \\
\text { CATA } & =\text { ratio of current assets to total assets } \\
\text { QUICK } & =\text { ratio of current assets (less inventories) to current liabilities } \\
\text { DE } & =\text { ratio of long-term debt to total assets } \\
\text { ROA } & =\text { ratio of earnings before extraordinary items to total assets } \\
\text { FOREIGN } & =\text { proportion of total sales from foreign operations } \\
\text { OPINION } & =\text { indicator variable, } 1=\text { qualified audit report }
\end{aligned}
$$




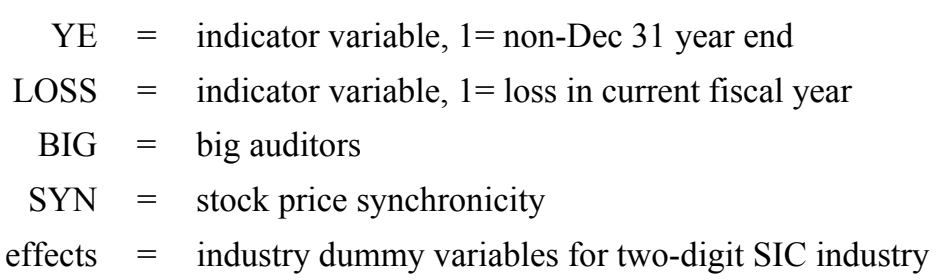

The eight industry groups are two-digit SIC code of $13,48,49,35,38,36,28,73$ with more than 500 observations for each industry.

The annual regression results in Table 4 indicate that the coefficient on SYN is positive and significant in 2004, but the coefficients on SYN are insignificant in 2005 and 2006, supporting both Hypotheses 1 and 2.

\subsection{Additional Tests}

This research conducts additional tests on reverse causality. The results remain unchanged after using simultaneous equations which takes into account that firms may incorporate firm-specific audit fees or abnormal audit fees into stock prices.

\section{Conclusion}

The results of this study support that SYN measures both informativeness and noise in different situations. This provides new insights to reconcile the mixed findings of the SYN literature regarding whether SYN measures informativeness or noise. This study suggests that SYN measured market-wide financial statement-related informativeness in times of regulatory changes in 2004 and SYN measured noise in other times such as in 2005 and 2006.

Moreover, the results may suggest that the benefit of SOX internal control requirements on overall market-wide informativeness is temporary (only in one year 2004); the cost of the high level of audit fees from 2004 afterward due to SOX may not justify the temporary benefit.

In summary, this research contributes to both SYN literature and audit pricing literature. First, this research provides empirical evidence that SYN measured market-wide financial statement-related information in times of regulatory changes affecting financial statements (e.g. SOX section 404) in 2004, and that SYN measured market-wide noise or sentiment in 2005 and 2006, which was usually non-financial statement related. This provides new insights to reconcile of mixed results of prior SYN literature. Second, this research contributes to audit pricing literature by documenting empirical evidence that market-wide financial statement-related information, such as internal control disclosure requirements, affects the auditor's risk assessment and, as a result, incurs higher audit fees.

\section{Acknowledgement}

This study is based on a part of my PhD thesis conducted at the School of Accounting and Finance of the Hong Kong Polytechnic University. I also gratefully appreciate the research grant provided by the National Natural Science Foundation of China (approval numbers: 71202090). 


\section{References}

A.R.C. Morgan. (2005). Sarbanes-Oxley Implementation costs, what companies are reporting in

their filings. $\quad$ SEC line $]$ Available at: http://www.auditnet.org/system/resources/BAhbBlsHOgZmSSJEMjAxMy8wMy8zMS8xMy 8xMi81My81MzcvU2FyYmFuZXNfT3hsZXlfSW1wbGVtZW50YXRpb25fQ29zdHMucGR mBjoGRVQ/Sarbanes-Oxley_Implementation_Costs.pdf (August 1, 2014)

Ashbaugh, H., LaFond, R., \& Mayhew, B.W. (2003). Do non-audit services compromise independence? further evidence. The Accounting Review, 78(3), 611-639. http://dx.doi.org/10.2308/accr.2003.78.3.611

Chan, K., \& Hameed, A. (2006). Stock price synchronicity and analyst coverage in emerging markets. Journal of Financial Economics, 80(1), 115-147. http://dx.doi.org/10.1016/j.jfineco.2005.03.010

Congress. (2002). The Sarbanes-Oxley Act of 2002.

DeFond, M., Raghunandan, K., \& Subramanyam, K. (2002). Do non-audit service fees impair auditor independence? Evidence from going concern audit opinions. Journal of Accounting Research, 40, 1247-1274. http://dx.doi.org/10.1111/1475-679X.00088

Durnev, A., Morck, R., \& Yeung, B. (2004). Value enhancing capital budgeting and firm-specific stock return variation. Journal of Finance, 59(1), 65-105. http://dx.doi.org/10.1111/j.1540-6261.2004.00627.x

Durnev, A., Morck, R. Yeung, B., \& Zarowin, P. (2003). Does greater firm-specific return variation mean more or less informed stock pricing? Journal of Accounting Research, 41(5), 797-836. http://dx.doi.org/10.1046/j.1475-679X.2003.00124.x

Francis, J., Reichelt, K., \& Wang, D. (2005). The pricing of national and city-specific reputations for industry expertise in the U.S. audit market. The Accounting Review, 80(1), 113-136. http://dx.doi.org/10.2308/accr.2005.80.1.113

Frankel, R., Johnson, M., \& Nelson, K. (2002). The relation between auditors' fees for non-audit services and earnings management. The Accounting Review, 77, 71-105. http://dx.doi.org/10.2308/accr.2002.77.s-1.71

Gul, F.A., \& Tsui. S.L. (1998). A test of the free cash flow and debt monitoring hypotheses: evidence from audit pricing. Journal of Accounting and Economics, 24, 219-237. http://dx.doi.org/10.1016/S0165-4101(98)00006-8

Jin, L., \& Myers, S. (2006). $\mathrm{R}^{2}$ around the world: New theory and new tests. Journal of Financial Economics, 79, 257-292. http://dx.doi.org/10.1016/j.jfineco.2004.11.003

Li, B., Rajgopal, S., \& Venkatachalam, M. (2014). $R^{2}$ and Idiosyncratic Risk Are Not Interchangeable. The Accounting Review. In-Press.

Morck, R., Yeung, B., \& Yu, W. (2000). The information content of stock markets: why do emerging markets have synchronous stock price movements? Journal of Financial Economics, 58(1-2), 215-260. http://dx.doi.org/10.1016/S0304-405X(00)00071-4

Palmrose, Z. (1986). The effect of non-audit services on the pricing of audit services: Further 
evidence. Journal of Accounting Research, 24, 405-411. http://dx.doi.org/10.2307/2491144

Palmrose, Z. (1988). An analysis of auditor litigation and audit service quality. The Accounting Review, 63, 55-73.

Piotroski, J., \& Roulstone, D. (2004). The influence of analysts, institutional investors, and insiders on the incorporation of market, industry, and firm-specific information into stock $\begin{array}{llll}\text { prices. The } \quad \text { Accounting } & \text { Review, } & \text { 1119-1151. }\end{array}$ http://dx.doi.org/10.2308/accr.2004.79.4.1119

Roll, R. (1988). R². Journal of Finance, 43(July),541-566.

Simunic, D. (1980). The pricing of audit services: theory and evidence. Journal of Accounting Research, 18(1), 161-190. http://dx.doi.org/10.2307/2490397

Skaife, H., Gassen, J., \& LaFond, R. (2006). Does stock price synchronicity represent firm-specific information? The international evidence. Working paper, University of Wisconsin-Madison, Humboldt University Berlin and Massachusetts Institute of Techonology.

Wang X.H., \& Yang Bibo. (2011). Management Entrenchment, Agency Problem and Audit Fees. Asia Journal of Finance \& Accounting, 3, 26-38. http://dx.doi.org/10.5296/ajfa.v3i1.932

Watts, R., \& Zimmerman, J. (1980). The markets for independence and independent auditors. Unpublished manuscript (University of Rochester)

Xing, X., \& Anderson, R. (2011). Stock price synchronicity and public firm-specific information. Journal of Financial Markets, 14(2), 259-276. http://dx.doi.org/10.1016/j.finmar.2010.10.001

\section{Copyright Disclaimer}

Copyright reserved by the author.

This article is an open-access article distributed under the terms and conditions of the Creative Commons Attribution license (http://creativecommons.org/licenses/by/3.0/). 